Ya. A. Kulbashna ${ }^{1}$

ORCID https://orcid.org/0000-0002-2571-091X

Ya. P. Nahirnyj ${ }^{2}$

ORCID https://orcid.org/0000-0002-1530-0271

I. L. Skrypnyk ${ }^{1}$

ORCID https://orcid.org/0000-0002-3393-4649

O. O. Skibitska ${ }^{1}$

ORCID https://orcid.org/0000-0002-3610-9927

V. O. Zakharova ${ }^{1}$

ORCID https://orcid.org/0000-0002-8863-2373

${ }^{1}$ O. Bohomolets National Medical University

${ }^{2}$ I. Horbachevsky Ternopil National Medical University

\title{
PROFESSIONAL TRAINING OF MASTERS IN DENTISTRY IN MEDICAL UNIVERSITIES OF UKRAINE AND COUNTRIES OF THE EUROPEAN UNION IN TERMS OF EDUCATIONAL CURRICULA AND SYLLABI HARMONIZATION
}

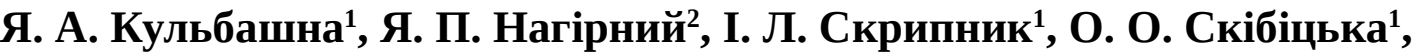

В. О. Захарова ${ }^{1}$

${ }^{1}$ Національний медичний університет імені О. О. Богомольця

${ }^{2}$ Тернопільський національний медичний університет імені І. Я. Горбачевського МОЗ Украӥни ПРОФЕСІЙНА ПІДГОТОВКА МАГІСТРІВ ІЗ СТОМАТОЛОГІЇ У МЕДИЧНИХ ЗАКЛАДАХ ВИЩОЇ ОСВІТИ УКРАЇНИ І КРАЇНАХ ЄВРОПЕЙСЬКОГО СОЮЗУ В КОНТЕКСТІ ГАРМОНІЗАЦІЇ ОСВІТНІХ ПРОГРАМ ТА НАВЧАЛЬНИХ ПЛАНІВ

Abstract. The article analyzes, compares and summarizes the curricula for masters in dentistry used in medical universities of the EU countries and O. Bohomolets National Medical University. A comparative analysis of European and national universities' curricula revealed that the professional training of masters in dentistry in medical universities of Ukraine and in European countries has significant differences in both content and organizational context. Curricula for professional training of future dentists in European universities differ in the number of disciplines and ECTS credits allocated for their study. Comparing of syllabi in NMU and EU countries allowed to state that the main differences consists in their intensity. It is established that the workload of students of national medical universities is very high on account of the large number of humanities and socio-economic disciplines, while European students have only two socio-economic disciplines in the program. Comparative analysis of curricula of national and European universities made it possible to determine the main tasks of reforming the system of dental education, particularly: improving the quality of medical education, ensuring its continuity and consistency throughout the period of professional activity; reducing the workload on students; providing the optimal ratio of theoretical and practical training with increasing emphasis on clinical and practical training.
\end{abstract}

Key words: academic mobility; curriculum; educational program; professional competence; practical training.

Анотація. У статті проаналізовано, порівняно й узагальнено навчальні плани підготовки магістрів у галузі стоматології медичних університетів країн ЄС і Національного медичного університету імені О. О. Богомольця. Порівняльний аналіз навчальних програм європейських та вітчизняних ЗВО виявив, що професійна підготовка магістрів із стоматології у медичних ЗВО України і у європейських країнах має суттєві відмінності як у змістовому, так і організаційному контексті. Навчальні плани підготовки стоматологів європейських 3ВО принципово різняться кількістю дисциплін та, відведених на їх вивчення, ECTS-кредитів. Порівняння навчальних планів підготовки стоматологів у НМУ та країнах ЄС дало змогу констатувати, що основні відмінності полягають у їх насиченості. Встановлено, що завантаженість студентів вітчизняних 3ВО дуже висока через велику кількість гуманітарних та соціально-економічних дисциплін, у той час як європейські студенти мають у програмі

(C) Ya. A. Kulbashna, Ya. P. Nahirnyj, I. L. Skrypnyk, O. O. Skibitska, V. O. Zakharova 
лише дві соціально-економічні дисципліни. Порівняльний аналіз навчальних програм вітчизняних та європейських ЗВО дав змогу визначити основні завдання реформування системи стоматологічної освіти, а саме: підвищення якості медичної освіти, забезпечення її безперервності і послідовності протягом усього періоду професійної діяльності; зменшення навчального навантаження на студентів; забезпечення оптимального співвідношення теоретичної та практичної підготовки із посиленням акценту на клінічно-практичній підготовці.

Ключові слова: академічна мобільність; навчальний план; освітня програма; професійна компетентність; практична підготовка.

Introduction. Ukraine's integration into the European educational and professional environment in the field of health care considers the harmonization of educational curricula and syllabi of future doctors' training, which are defined by the WFME as a basic factor in health education reform [11]. At the same time, their true compliance is a prerequisite for the introduction of students' academic mobility and specialists for further acknowledgement of diplomas in different countries, where graduates migrate as a result of globalization processes or with the purpose of their professional level improving by participating in different trainings [12]. Determining the comparability of Ukrainian medical universities' educational cirricula and syllabi with the foreign ones on the basis of comparative analysis will contribute to their optimization with the preservation of the best achievements in national science and practice.

The content of the reform in the EU countries on the competence-based approach, which ensures modern higher education quality, consists in providing radical changes of the educational paradigm in all basic fields: from goal setting to the organization of the educational process. The main tasks of reforming are the following branches: improving the quality of medical education, ensuring its continuity and consistency throughout the whole period of professional activity; reducing students' workload; formulation of medical education targets on the base of a new goal-setting methodology which consists in the formation of a competent and competitive doctor; constant updating of the education content in accordance with the development of natural sciences, medical knowledge and technologies and the needs of the health care system, its restructuring; ensuring the optimal ratio of theoretical and practical training with increasing emphasis on the clinical and practical component [5]. Modernization of the educational process contributed to a decisive change of the direction from knowledge to competence-based teaching model which promotes actualization and encourages to implement activity methodology of educational process with emphasizing importance of practical training and ensuring the graduate's ability to implement acquired knowledge into professional activity.
Modern approaches have been developed and implemented in order to increase the efficiency of the education reform process. The first one is a competence approach which aimed at the formation of scientifictheoretical, professional-practical, personal maturity of the graduate for practical activities in the health care system; taking into consideration the rapid pace of updating medical knowledge, another one is problemoriented approach that focuses on the formation of self-preparation skills, self-esteem and abilities to find own ways to solve problems in professional activities.

The reform of medical education in Ukraine began with joining the Bologna Process (2005), after which the national higher education system was formally integrated into the European one, where the number of ECTS credits in the educational curriculum and each subject was determined as an important factor. The amount of professional training credits is accepted as 300 units (minimum number) for future dentists. Nevertheless, diplomas of medical universities' graduates are still not recognized outside the country and specialists need to undergo long-term retraining [8].

Professional training of masters in dentistry has begun in accordance with the Law of Ukraine on higher education (2014) [2], the Resolution of the Cabinet of Ministers of Ukraine (2015) [6], the updated education standard (2019) in medical universities [7]. However, the analysis of scientific and normative-legal documents allowed to establish that the system of future dentists' professional training in Ukraine differs significantly from foreign ones [9].

After a long discussion among educators, the Ministry of Education and Science of Ukraine approved a new Standard of Higher Education in 221 Specialty "Dentistry" in the field of knowledge 22 "Public Health" for the second (master's) level of higher education - hereinafter Standard [7], where one of the significant achievements is introduction of alternative educational-professional (300 credits) curriculum and educational-scientific one in the amount of 360 credits.

This program significantly expands the prospects for the integration of national and European educational environment in the context of training masters in dentistry, especially according to the requirements of the 
WFME [13] and European Standards of Education [1]. Thus, there is a need to identify the main differences in the curricula and eliminate them without compromising the best achievements of the national medical school.

The aim of the study - to conduct analysis of educational curricula and syllabi for professional training of masters in dentistry in medical universities in Ukraine and in the European Union in the context of their harmonization.

During the research, the curricula for professional training of masters in dentistry of European medical universities and O. Bohomolets National Medical University (NMU) were analyzed, compared and generalized.

Theoretical framework. It is established that the main trends and basic principles of reforming the European medical education system are demonstrated by the Austrian model, the development of which began around the same time when Ukraine joined the Bologna Process and began modernization of its higher education.

Future dentists (a total amount of 80 graduates in each university) are trained by medical universities in Vienna, Innsbruck and Graz, which in 2002 separated from the classical universities and gained autonomy. After the introduction of the reform in medical universities a unification of curricula occurred, this facilitated the internal mobility of students. Among the notable innovations, it is necessary to mention that Universities of Vienna and Innsbruck introduced the entrancecontrol of suitability for medical studies [10].

With the purpose of eliminating the main source of resistance to change, the training of dentists is arranged as a one-stage six-year course which will be replaced by a two-stage one in future. It should be noted that the last year of study involves only clinical training which significantly improves the quality of practical training [9]. Similar models have proven their effectiveness in other EU countries (Netherlands, France, etc.).

Special attention needs to be paid to the changes in knowledge assessment methods that have been introduced in Austria and have significantly improved the quality of this key educational factor. Mostly, departments of foreign universities, unlike national medical universities, do not participate in independent testing, they prepare only a bank of test tasks and do not have access to the database of the tasks submitted for the exam; they are not allowed to review the results after exams which ensures transparency of the procedure [5].

Medical universities in Austria are cooperating actively with the National Monitoring Group for the implementation of the Bologna Declaration. One of the most important achievements is the approval of the diploma supplement (since 2002) which since October 2003 universities have been issuing in German and English to each graduate at his request (the issuance of diploma supplements is provided in other languages as well) [5]. Mentioned reforms promote the mobility of students in Europe, the recognition of new diplomas in the international labor market, facilitating the resumption of education. They allow students to focus on self-preparation, adjust the study schedule, and harmoniously combine all aspects of student life [3].

Syllabi for the training of dentists in Austria are fundamentally different from national ones as they provide study within the ECTS cycles for the formation of social, methodological, professional and personal competencies from the first year of training. It should be emphasized that it is supposed to achieve a high level of future dentists' competence while formulating the purpose and specific tasks of their professional training. Moreover, a feature of the Austrian model of dental education is the vertical structuring which includes the qualification level "doctor" (six years, 5500 hours) and is recognized as a professional qualification. The introduction of the basic qualification of a bachelor in medicine is possible due to the amendments to the Law about Universities issued in 2009. The achievement of the modernized Austrian medical school was the implementation of the principle of academic mobility at the pre- and postgraduate stages. This raises the level of its quality to other countries that have more experience in the Bologna Process [5].

A comparison of the syllabi for the dentists at NMU and VMU indicates that the main differences are the intention of these syllabi. From the first terms the workload of NMU students is very high as they have to study about 50 subjects in the first - third academic years (5720 hours in total), while in Vienna - 36 ones (2132 academic hours) with an average workload of six subjects per term. In addition, the final course is entirely composed of practical classes (72-week practice) while the last year in NMU contains lectures and seminars. The duration of training of future dentists at NMU is five years, and in Vienna - six ones [5].

It is necessary to mention that the introduction of academic mobility and integration within the European educational space requires perfect knowledge of a foreign language which can substantially increase the competitive capacity of future specialists. At the same time, analysis of normative-legal documents that 
standardize the formation of future dentists' foreign language competence in Ukrainian medical universities revealed the lack of academic hours for studying foreign language. O. Bohomolets National Medical University provide only 3 ESCT credits for foreign language learning when European universities ensure 6 ones [4]. Thus, there is a strong need to increase amount of practical classes for foreign language competence formation.
In order to specify the process of future dentists' professional training in Ukraine and the European Union, the working curricula of the O. Bohomolets National Medical University (Ukraine), Lithuanian University of Medical Sciences (Lithuania), Wroclaw Medical University (Poland) and Vienna Medical University (Austria) were compared. Their comparison was carried out according to the years of study and direction of disciplines (Table 1 and 2).

Table 1. The comparison of curricula in Ukrainian medical universities and medical universities of EU countries according to the direction of disciplines

\begin{tabular}{|c|c|c|}
\hline Country & The amount of disciplines & The amount of academic hours \\
\hline \multicolumn{3}{|c|}{ Humanitarian and socio-economic disciplines } \\
\hline Ukraine & 7 & 615 \\
\hline Lithuania & 3 & 952 \\
\hline Poland & 4 & 155 \\
\hline Austria & 2 & 120 \\
\hline \multicolumn{3}{|c|}{ Natural Science Disciplines (fundamental training) } \\
\hline Ukraine & 17 & 1210 \\
\hline Lithuania & 12 & 1101 \\
\hline Poland & 15 & 690 \\
\hline Austria & 8 & 536 \\
\hline \multicolumn{3}{|c|}{ Disciplines of general and professional training } \\
\hline Ukraine & 29 & 1365 \\
\hline Lithuania & 8 & 533 \\
\hline Poland & 23 & 910 \\
\hline Austria & 16 & 1146 \\
\hline \multicolumn{3}{|c|}{ Disciplines of professional and practical training } \\
\hline Ukraine & 11 & 2085 \\
\hline Lithuania & 16 & 2957 \\
\hline Poland & 22 & 2722 \\
\hline Austria & 16 & $1459+72$ weeks of practical classes \\
\hline
\end{tabular}

The analysis of Table 1 evidences that NMU students study 2 times more humanities and socio-economic disciplines than students in Lithuania and Poland, and almost three times more than learners in Austria. Thus, future dentists in Ukraine study seven of these disciplines with a total amount of 615 academic hours. Lithuanian students have three of mentioned disciplines with 952 academic hours, but 593 of them are allocated for elective courses, per one for each term. In the universities of Poland and Austria, only 155 and 120 academic hours are allocated for such disciplines correspondingly. Students of Polish universities also have elective courses, foreign language, physical education and separately allocated hours for studying in the library. Austrian students have only two disciplines from the humanitarian and socio-economic disciplines in the curriculum. They also have an elective course and sociology. It should be noted that none of the universities from mentioned countries of the European Union has in its program such disciplines as native language and history of the native country, with all due respect to the issues studied in their context.

The number of natural science disciplines (fundamental training) in the curricula of Ukrainian, Lithuanian and Polish universities is approximately the same and makes up 17, 15 and 12 correspondingly. However, the University of Poland provides almost 2 times more academic hours (690) for these disciplines comparing to Ukrainian (1210 hours) and to Lithuanian (1101 hours) one. All curricula contain such disciplines as human anatomy, histology, biology, 
chemistry, etc. The program of the Austrian university has substantial difference; it provides eight disciplines and 536 academic hours. Students also study human anatomy, but a significant number of hours are allocated to sections such as clinical anatomy of the head, neck and masticatory/skeletomuscular system.

It is worth paying special attention to the situation with the disciplines of general professional training. The NMU curriculum contains 29 disciplines and 1365 academic hours for them. At the same time, there are 23 disciplines and 1.5 time less academic hours (910) in Universities of Poland. Lithuania Universities provide the smallest amount of these disciplines and academic hours: 8 and 533 correspondingly. There are almost twice more disciplines in Austria than in Ukraine, but the number of hours is similar: 16 and 1146 correspondingly. All programs include such disciplines as pathomorphology, pathophysiology, pharmacology and general medical training.However, dental students of Ukrainian universities study mentioned disciplines thoroughly, which is an obvious advantage in the context of their general medical erudition and ensuresprofound understanding of pathological processes development.

Ukrainian students have the least amount of academic hours allocated for disciplines related to professional and practical training which are considered as the most important in the training of future specialists. The curriculum of NMU provides 11 disciplines and 2085 academic hours, which include on-the-job training. Unfortunately, it is not divided into narrow branches, but it is represented by general disciplines in accordance with existing departments: orthopedic, therapeutic and surgical dentistry; pediatric dentistry and introduction to clinical dentistry (propaedeutics).

In the universities of Lithuania and Austria, the number of disciplines is the same per 16 , which is 5 times more than in Ukraine, but the number of academic hours is much more. Thus, 2957 academic hours are allocated for professional disciplines in Lithuanian universities. Austrian universities provide 1459 academic hours and separately 72 weeks of practical classes. It is worth mentioning that 36 weeks of practical classes for Austrian students fall on the sixth year of study in contrast to the other universities with five years of study; nevertheless, the number of academic hours for professional disciplines will exceed in Ukrainian universities.

Comparison of curricula, according to the amount of disciplines per year, is presented in the Table 2.

The analysis of the Table 2 revealed that NMU students have proportional distribution of all disciplines over five years of study. Ukrainian students have from 14 to 17 subjects for one year and one thousand academic hours on average.

Over five years of study, students have 78 subjects, including 5275 academic hours of on-the-train-job. About $40 \%$ (2085) of academic hours are allocated to professional disciplines. The discipline "Introduction to Clinical Dentistry" appears only in the spring-summer term of the second year, while in the universities of Poland and Austria professional disciplines are taught from the first term.

The biggest amount of subjects and, at the same time, less academic hours are provided by Wroclaw Medical University during the five years of study: 84 subjects and 4560 hours. However, about $60 \%$ (2722) of academic hours are allocated for professional disciplines. Starting from the first term students study the dental oriented disciplines for example "Ergonomics in dentistry".

The curriculum of Lithuanian Medical University includes 62 subjects and 5707 academic hours. The number of subjects in this university is less than in NMU, and the number of hours is approximately $10 \%$ more. Professional disciplines make up 50 \% (2957) of all academic hours and appear during the second year of study the same as in Ukrainian university.

The smallest number of subjects appears in the curriculum of the Vienna Medical University: only 48 subjects and 5233 academic hours for six years of study. Dental oriented disciplines make up $70 \%$ (3619) of academic hours. Like in Polish university, professionally-oriented subjects are taught during the first year, such as "Propaedeutics of Dentistry". It is important that the last year of study is entirely devoted to practical classes lasting 36 weeks.

Thus, the largest number of disciplines in Ukrainian and Polish medical universities is per 64 in each country, there are 42 disciplines in Austrian university and the smallest amount of disciplines appear in Lithuanian university (39 ones). The number of academic hours is approximately equal, only in Wroclaw Medical University it is less than 1000 hours. The distribution of disciplines by years of study, except for the Austrian university, is approximately the same in all universities and ranges from 14 to 18 . Vienna Medical University provides about 10 disciplines during four years of study and 2-3 disciplines and 36 weeks of practical classes during the fifth and sixth years.

The difference in the number of academic hours while comparing disciplines and years of study in medical universities of the EU can be explained by the presence of hours allocated for different types of exams 
Table 2. Comparison of curricula in Ukrainian universities and in the countries of the EU according to years of study

\begin{tabular}{|c|c|c|}
\hline Country & The amount of disciplines & The amount of academic hours \\
\hline \multicolumn{3}{|c|}{ I year of study } \\
\hline Ukraine & 16 & 1120 \\
\hline Lithuania & 15 & 1113 \\
\hline Poland & 18 & 685 \\
\hline Austria & 12 & 405 \\
\hline \multicolumn{3}{|c|}{ II year of study } \\
\hline Ukraine & 16 & 1125 \\
\hline Lithuania & 14 & 1152 \\
\hline Poland & 18 & 725 \\
\hline Austria & 13 & 688 \\
\hline \multicolumn{3}{|c|}{ III year of study } \\
\hline Ukraine & 17 & 1000 \\
\hline Lithuania & 13 & 1172 \\
\hline Poland & 17 & 1058 \\
\hline Austria & 9 & 809 \\
\hline \multicolumn{3}{|c|}{ IV year of study } \\
\hline Ukraine & 15 & 1050 \\
\hline Lithuania & 14 & 1170 \\
\hline Poland & 16 & 1099 \\
\hline Austria & 9 & 877 \\
\hline \multicolumn{3}{|c|}{$\mathrm{V}$ year of study } \\
\hline Ukraine & 14 & 980 \\
\hline Lithuania & 6 & 1100 \\
\hline Poland & 15 & 993 \\
\hline Austria & 2 & 137 \\
\hline Ukraine & 3 & 157 \\
\hline \multicolumn{3}{|c|}{ VI year of study } \\
\hline Austria & & 36 weeks practical classes \\
\hline
\end{tabular}

which are not provided in the programs of universities in our country.

Unfortunately the smallest amount of academic hours (2085) is allocated for professionally oriented disciplines according to the curriculum of future dentists' professional training in Ukraine. It consists only $40 \%$. Medical universities of the European Union countries provide at least $50 \%$ of the total number of academic hours for professional discipli

It is important to emphasize that the training of masters in national medical univesities, in contrast to European ones, does not require mandatory writing and delivering of scientific (master's) work which limits the graduate's ability to search, analyze, synthesize and use scientific information in professional activities [3].

Thus, the analysis of the international experience of future dentists' professional competence formation allowed to reveal significant differences in comparison with national medical education. The following weak points were noted: the minimum training period in comparison with the leading Western models
(Germany, Austria, Switzerland), the absence of clinical and practical year of study; overload of syllabi with the number of disciplines and the amount of academic hours; less time for self-preparation and practical training; the absence of hours in the curriculum aimed at the formation of basic competencies; the block of disciplines "humanitarian and socio-economic training" is almost twice larger than in the EU; noncorrespondance of names and content of disciplines; a lack of a number of important special disciplines (for example, biology of the oral cavity, gerontology in dentistry, etc.); professional disciplines are not taught during the first year. The experience of Austrian university is considered beneficial to follow.

Conclusions and Prospects for Research. Professional training of masters in dentistry in medical universities of Ukraine and the European Union has significant differences in both content and organizational context. For the successful integration of national higher medical education into the European environment of higher education, it is necessary to ensure the 
harmonization of educational curricula and syllabi based on the best models of EU countries, including

\section{List of literature}

1. Директива Європейського Союзу щодо визнання професійних кваліфікацій від 2005 року (№ 2005/36/ ЄС з поправками Директиви Європейського Союзу № 2013/55/ЄC).

2. Закон України «Про вищу освіту» // Урядовий кур’єр. - 2014. - № 146 (13 серпня). - С. 7-18.

3. Інструкція щодо оцінювання навчальної діяльності студентів в умовах впровадження Європейської кредитно-трансферної системи організації навчальної процесу, затвердженої МОЗ України 15.04.2014 р. [Електронний ресурс]. - Режим доступу : https:// www.bsmu.edu.ua/wp-content/uploads/2020/03/bdmuinstrukcziya-shhodo-oczinyuvannya-\%D1\%94kts-2014-3. pdf.

4. Кульбашна Я. А. Портфоліо як інструмент формування праксеологічної компетентності майбутніх фахівців із стоматології / Я. А. Кульбашна, І. Л. Скрипник, В. О. Захарова // Педагогічний процес: теорія і практика. - 2019. - № 3-4. - С. 67-76.

5. Кульбашна Я. А. Формування професійної компетентності майбутніх фахівців із стоматології: теоретичні й методичні основи : монографія / Я. А. Кульбашна. К. : ВПП «Компас», 2014. - 416 с.

6. Про затвердження переліку галузей знань і спеціальностей, за якими здійснюється підготовка здобувачів вищої освіти : Постанова Кабінету Міністрів України від 29.04.2015 р. № 266 [Електронний ресурс]. - Режим доступу : https://www.kmu.gov.ua/npas/248149695.

\section{References}

1. Dyrektyva Yevropeiskoho soiuzu shchodo vyznannia profesiinykh kvalifikatsii vid 2005 roku [Directive of the European Union on the recognition of professional qualifications]. [in Ukrainian].

2. (2014). Zakon Ukrainy "Pro vyshchu osvitu" [Law of Ukraine “On higher education”]. Uriadovyi kurier - Government Courier, 146, 7-18 [in Ukrainian].

3. Instruktsiia shchodo otsiniuvannia navchalnoi diialnosti studentiv v umovakh vprovadzhennia Yevropeiskoi kredytnotransfernoi systemy orhanizatsii navchalnoi protsesu, zatverdzhenoi MOZ Ukrainy 15.04.2014 [Instruction on students'performance assessment in terms of ECTS system implementation approved by Ministry of public Health of Ukraine]. Retrieved from: https://www.bsmu.edu.ua/wpcontent/uploads/2020/03/bdmu-instrukcziya-shhodo-oczinyuvannya-\%D1\%94kts-2014-3.pdf [in Ukrainian].

4. Kulbashna, Ya.A., Skrypnyk, I.L., \& Zakharova, V.O. (2019). Portfolio yak instrument formuvannia prakseolohichnoi kompetentnosti maibutnikh fakhivtsiv iz stomatolohii [Portfolio as a tool of praxiological competence
Austria, which allows to increase significantly the level of practical training of graduates.

7. Стандарт вищої освіти України другого (магістерського) рівня галузі знання 22 «Охорона здоров’я», спеціальності 221 «Стоматологія» // Наказ Міністерства освіти і науки України 24.06.2019 р. № 879 [Електронний ресурс]. - Режим доступу : http://www.testcentr.org.ua/ index.php/menu-methwork/menu-dsvo/60-s-methwork/110gsvou.html.

8. Стратегія реформування вищої медичної освіти [Електронний ресурс]. - Режим доступу : https://moz. gov.ua/article/reform-plan/moz-ukraini-opriljudnilo-dljagromadskogo-obgovorennja-strategiju-rozvitku-medichnoiosviti.

9. A modern model of master's in dentistry professional training / Ya. A. Kulbashna, V. O. Malanchuk, I. L. Skrypnyk [et al.] // Медична освіта. - 2020. - № 1. - P. 45-49.

10. Eignungstest für das Medizinstudium in Österreich. - Access mode : https://apps.derstandard.at/privacywall/1343743730235/Mediziner-Test-Maenner-fuehlensich-benachteiligt.

11. International Standards in Basic Medical Education, WFME Task Force on Defining International Standards in Basic Medical Education. - 2000. - P. 665-675.

12. Turning educational structure in Europe. - Access mode : http:// turning.unideusto.org.

13. WFME Global Standards for Quality Improvement in Medical Education European Specifications / WFME/AMSE International Task Force MEDINE Quality Assurance Task Force University of Copenhagen Denmark 2007 Printed by: Kandrups Bogtrykkeri A/S. - 79 p.

formation of future dentists]. Pedahohichnyi protses: teoriia i praktyka-Pedagogical process: Theory and Practice, 3-4, 67-76 [in Ukrainian].

5. Kulbashna, Ya.A. (2014). Formuvannia profesiinoi kompetentnosti maibutnikh fakhivtsiv iz stomatolohii: teoretychni i metodychni osnovy: monohrafiia [Future dentists'professional competence formation: theoretical and methodological bases: monography]. Kyiv: VPP "Kompas" [in Ukrainian].

6. Postanova Kabinetu Ministra Ukrainy vid 29.04.2015 № 266 “Pro zatverdzhennia pereliku haluzei znan $i$ spetsialnostei, za yakymy zdiisniuietsia pidhotovka zdobuvachiv vyshchoi osvity" [Resolution of the Cabinet of Ministers of Ukraine dated April 29, 2015 No. 266 “On approval of the list of knowledge branches and specialties for which higher education students are trained"]. Retrieved from:https://www.kmu.gov.ua/npas/248149695 [in Ukrainian].

7. Standart Vyshchoy Osvity Ukrainy Druhoho (mahisterskoho) rivnia haluzi znannia 22 - Okhorona zdorovia, spe- 
tsialnosti 221 - Stomatolohiia. Nakaz Ministerstva osvity i nauky Ukrainy 24.06.2019r. №879. [Standard of Higher Education of Ukraine of the Second (master's) level of knowledge 22 - Health care, specialty 221 - Dentistry. Issue of the Ministry of Education and Science of Ukraine June 24, 2019 No. 879]. Retrieved from: http://www.testcentr.org.ua/ index.php/menu-methwork/menu-dsvo/60-s-methwork/110gsvou.html [in Ukrainian].

8. Stratehiia reformuvannia vychshhoi medychnoi osvity [Strategy for higher medical education reforming]. Retrieved from: https://moz.gov.ua/article/reform-plan/ moz-ukraini-opriljudnilo-dlja-gromadskogo-obgovorennjastrategiju-rozvitku-medichnoi-osviti [in Ukrainian].

9. Kulbashna, Ya.A., Malanchuk, V.O., Skrypnyk, I.L., Nahirnyi, Ya.P., \& Zakharova, V.O. (2020). A modern model of master's in dentistry professional training. Medychna osvita - Medical Education, 1, 45-49.

10. Eignungstest für das Medizinstudium in Österreich. Retrieved from: https://apps.derstandard.at/privacywall/1343743730235/Mediziner-Test-Maenner-fuehlen-sich-benachteiligt.

11. (2000). International Standards in Basic Medical Education. WFME Task Force on Defining International Standards in Basic Medical Education.

12. Turning educational structure in Europe. Retrieved from: http:// turning.unideusto.org.

13. (2007). WFME Global Standards for Quality Improvement in Medical Education European Specifications / WFME/AMSE International Task Force MEDINE Quality Assurance Task Force University of Copenhagen Denmark. Kandrups Bogtrykkeri.

E-mail address for correspondence: valerieozakharova@gmail.com 